\title{
Ethnobotanical survey of medicinal plants used by the Mamanwa tribe of Surigao del Norte and Agusan del Norte, Mindanao, Philippines
}

\author{
OLGA M. NUNEZA ${ }^{1, \vartheta}$, BIVERLY C. RODRIGUEZ ${ }^{2, v »}$, JULIET GRACE M. NASIAD \\ ${ }^{1}$ Department of Biological Sciences, College of Science and Mathematics, Mindanao State University-Iligan Institute of Technology. Tibanga, Iligan \\ City, Lanao del Norte, Mindanao, Philippines. Tel./fax.: +63-2214065, •email: olga.nuneza@g.msuiit.edu.ph \\ ${ }^{2}$ Premier Research Institute of Science and Mathematics, Mindanao State University, Tibanga, Iligan City, Lanao del Norte, Mindanao, Philippines. \\ vemail: biverly.rodriguez@g.msuiit.edu.ph, vvv julietgrace.nasiad.@g.msuiit.edu.ph
}

Manuscript received: 11 January 2021. Revision accepted: 23 May 2021.

\begin{abstract}
Nuneza OM, Rodriguez BC, Nasiad JGM. 2021. Ethnobotanical survey of medicinal plants used by the Mamanwa tribe of Surigao del Norte and Agusan del Norte, Mindanao, Philippines. Biodiversitas 22: 3284-3296. Traditional knowledge on medicinal plants plays an important role in public healthcare and development of drugs. In the Philippines, studies on ethnomedicinal plants have increased throughout the years. However, documentation on the ethnobotanical knowledge in Mindanao is few and mostly focused on other well-known tribes. This ethnobotanical study was carried out to document medicinal plants used by the Mamanwas tribe in ten Indigenous Cultural Communities (ICCs) of Surigao del Norte and Agusan del Norte, Philippines. Ethnomedicinal information on the plant parts used, different modes of preparation, and mode of utilization was gathered from 143 local informants through informal interviews and semi-structured questionnaires. Seventy-eight plant species under 70 genera and 42 families were documented to treat various ailments in their communities. Family Asteraceae held the dominance with ten species that were reported to have medicinal uses. Out of the 78 species, trees constituted the largest proportion with 32 plant species that cover $41 \%$. In terms of plant parts used, leaves are frequently used constituting $46 \%$. As to mode of preparation, decoction (40\%) ranked the highest followed by poultice (18\%) and heating over fire (14\%). Documentation of the valuable ethnomedicinal knowledge will help preserve the vanishing tradition of cultural communities in terms of medicinal plant utilization.
\end{abstract}

Keywords: Ethnomedicinal, healthcare, herbal, traditional knowledge

\section{INTRODUCTION}

Ethnobotany includes the study of how indigenous communities of a specific location uses plants for food, clothing, housing, and medicine (Aiyeloja and Belo 2006). As old as human civilization, people use plants as source of drugs for treatment, prevention of diseases, and for the promotion of good health (Alpuerto et al. 2010) through trial-and-error method (Patil 2012). This indigenous knowledge on traditional medicinal plants is passed on from generation to generation by oral tradition especially to the cultural group. Much of this traditional knowledge has been kept secret from the outsider's world (Majumdar and Datta 2007). This indicates that the great wealth of knowledge on economically useful plants and traditional techniques used to manage, harvest, and conserve these species rely on cultural groups (Soejarto et al. 2009).

According to the World Health Organization (2005), about $80 \%$ of the population of the world depends on traditional medicine, mostly herbal remedies, for their primary health care need. Ethnobotanical surveys conducted in different parts across Asia contribute to the existing repository of traditional ethnobotanical knowledge. For example, Keo et al. (2018) documented 50 species of medicinal plants in Cambodia that have been customarily used to treat common ailments while the survey of Sharmila et al. (2018) on some plant species in Nainamalai Foothill in the Eastern Ghats recorded a total of 124 plants used in a variety of medicinal applications. Meanwhile, the study of Taek et al. (2018) reported several ethnomedicinal plants as treatment for malaria in Malaka, West Timor. On the other hand, the findings of Zain-ul-Abidin et al. (2018) revealed that 40 highly anti-diabetic plant species used in South Pakistan for the treatment and control of diabetes mellitus type II are reported for the first time.

The Philippines is recognized as one of the earth's most important biodiversity hotspots (Gaither and Rocha 2013) with approximately 13000 plant species of which 39\% of them are considered as endemics (Banag-Moran et al. 2020). Many of these plants are widely used as traditional alternative medicine (Quisumbing 1978). The practice of using plants as medicine in the Philippines dates back to Spanish pre-colonial era that continued for the next three hundred years during the Spanish occupation in the Philippines. Documentation on herbal medicines such as manuscripts and books were mostly done by Spanish missionaries and after which, American colonization took over which have led to the scientific approach on studying medicinal plants (Joven 2012). According to Quisumbing (1978), poor medicinal supplies during World War II resulted to the demand for extensive research on medicinal plants as an answer to the need for ethnopharmacological and other related studies to be carried out to solve the problem on the scarcity of imported drugs and medicines. Nonetheless, despite the long history of plants used traditionally for medicinal purposes in the Philippines, as 
of the present there are only ten plant species approved by the Philippine Department of Health as scientifically proven alternative medicines for certain conditions (Galvez-Tan and Sia et al. 2014; Heinrich and Jager 2015).

Several studies conducted in all parts of the country documented various plant species used by the local people. The study of Maghanoy et al. (2013) recorded 46 medicinal plant species in Bukidnon that are used by three tribes in treating various illnesses. Gurrea (1993) presented 20 species of common medicinal plants with information gained through interviews with local healers from several municipalities in Bukidnon from 1986 to 1987. Cuyacot et al. (2014) collected five species of medicinal plants based on ethnopharmacological uses of the inhabitants of Mt. Nebu, Bukidnon. In Agusan Del Sur, Arquion et al. (2015) found that the plant species, Ficus nota knew as "tibig" is traditionally used by the Manobo tribe in Talacogon as alternative medicine. Trono et al. (2016) reported that the Manobo tribe in Bukidnon traditionally uses the bark decoction of Trema orientalis as treatment for diabetes.

Considering the wealth of indigenous knowledge on medicinal plants in the country, it is necessary to conduct studies on medicinal plants utilized by lesser-known tribes like the Mamanwas in Surigao and Agusan provinces in Mindanao. Thus, this study aims to document the local names of the medicinal plants used by the Mamanwas and identify the plants according to common name and scientific name, record the habit of growth and plant parts utilized for medicine, and document the ailments treated, mode of application and the different mode of preparation of the medicinal plants used by the Mamanwa tribe in Surigao del Norte and Agusan del Norte, Philippines.

\section{MATERIALS AND METHODS}

\section{Study area and period}

The study was conducted in the province of Surigao del Norte $\left(9^{\circ} 30^{\prime}\right.$ to $9^{\circ} 35^{\prime} \mathrm{N} 125^{\circ} 34^{\prime}$ to $\left.125^{\circ} 52 \mathrm{E}\right)$ and Agusan del Norte (9 $9^{\circ} 26^{\prime}$ to $9^{\circ} 27^{\prime} \mathrm{N} 125^{\circ} 34^{\prime}$ to $125^{\circ} 36 \mathrm{E}$ ) which are two of the five provinces belonging to CARAGA region in Mindanao, Philippines (Figure 1). The whole duration of survey and plant sample collection was conducted from July 11, 2019, to November 15, 2019. Surigao del Norte mainly consists of three major islands such as Siargao Island, Dinagat Island, and Bucas Grande Island. The province is divided into 20 municipalities and 335 barangays. In terms of topography, the mainland portion of Surigao del Norte is composed of varied terrain ranging from flat to rugged mountains. On the other hand, Agusan del Norte consists of mountains in its northeastern and western parts and in between is mostly flat and rolling lands. It is composed of 10 municipalities and 165 barangays and is the second smallest province in the region.

Typically, the Mamanwa tribe of the area still relies on medicinal plants which are found within their ancestral land to treat various kind of ailments and diseases. This study covered four municipalities of Surigao Del Norte (i.e., Bacuag, Claver, Gigaquit and Tubod) and one municipality of Agusan Del Norte (i.e., Kitcharao) which is within the ancestral land CADT-048. Ten Indigenous Cultural Communities (ICC) that are occupied by the Mamanwa tribe were selected as sampling sites, namely: Sitio Puyawon ( $9^{\circ} 32^{\prime} 50.2^{\prime \prime}$ N $125^{\circ} 40^{\prime} 56.6^{\prime}$ ' E), ICC of Sitio Palalihan ( $9^{\circ} 30^{\prime} 20^{\prime}$ ' N $125^{\circ} 40^{\prime} 24.4^{\prime \prime}$ E) and ICC of Sitio Tiltilan ( $9^{\circ} 32^{\prime}, 28.2^{\prime}$ ' N $125^{\circ} 40^{\prime} 3.5^{\prime}$, E) of the Municipality of Gigaquit; ICC of Sitio Baliw ( $9^{\circ} 32^{\prime}$ '17.4',

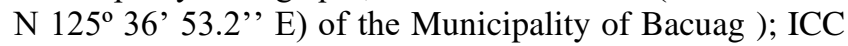
of Barangay Cawilan ( $9^{\circ} 32^{\prime}$ 58.4'" $\mathrm{N} 125^{\circ} 34^{\prime} 53.6^{\prime \prime} \mathrm{E}$ ) and ICC of Barangay Timamana ( $9^{\circ} 35^{\prime} 38.6^{\prime \prime} \mathrm{N} 125^{\circ} 34^{\prime}$ $25.2^{\prime \prime}$ E) of the Municipality of Tubod ); ICC of Sitio Bliss (9' 27' 20.9' ' N 125 34' 51.5', E) and ICC of Barangay Mahayahay ( $9^{\circ} 26^{\prime} 48.3^{\prime \prime} \mathrm{N} 125^{\circ} 35^{\prime} 15.2^{\prime}$ ' E) of the Municipality of Kitcharao; ICC of Barangay Urbiztondo ( $9^{\circ} 30^{\prime} 52^{\prime}$ ' N 125 $52^{\circ} 28.5^{\prime}$ ' E) and ICC of Barangay Taganito ( $9^{\circ} 30^{\prime} 48^{\prime}, \mathrm{N} 125^{\circ} 52^{\prime} 31.1^{\prime}$, E) of the Municipality of Claver.

\section{Free-Prior and Informed Consent (FPIC)}

Prior informed consent was secured following the guidelines on Free and Prior Informed Consent (FPIC) and related process stipulated in the National Commission on Indigenous Peoples (NCIP) Administrative Order No. 3 Series of 2012 in compliance with the implementing rules and regulations of Republic Act No. 8371 or otherwise known as The IPRA Law (Indigenous Peoples' Rights Act). First, an application for the issuance of certification of precondition was submitted together with the project proposal at the NCIP Regional Office that has jurisdiction over the proposed study area. Once the application was submitted, the NCIP Regional director forwarded the request to the responsible NCIP Provincial Office and identified the Field-Based Investigation (FBI) Team which is composed of the Provincial Officer as the team leader and the corresponding members. Then, a Pre-FPIC Conference organized by the FPIC Team was attended by the research team together with the Mamanwa tribal leaders. During the Pre-FPIC Conference, the proposed study was presented to the tribal leaders and as an output, work and financial plan were formulated and agreed upon. A series of meetings such as the first and the second community assemblies were conducted. After the Mamanwa tribal leaders had given their consent to the project to conduct research in their area, the MOA (Memorandum of Agreement) presentation/ finalization and signing as well as the ritual were conducted. 

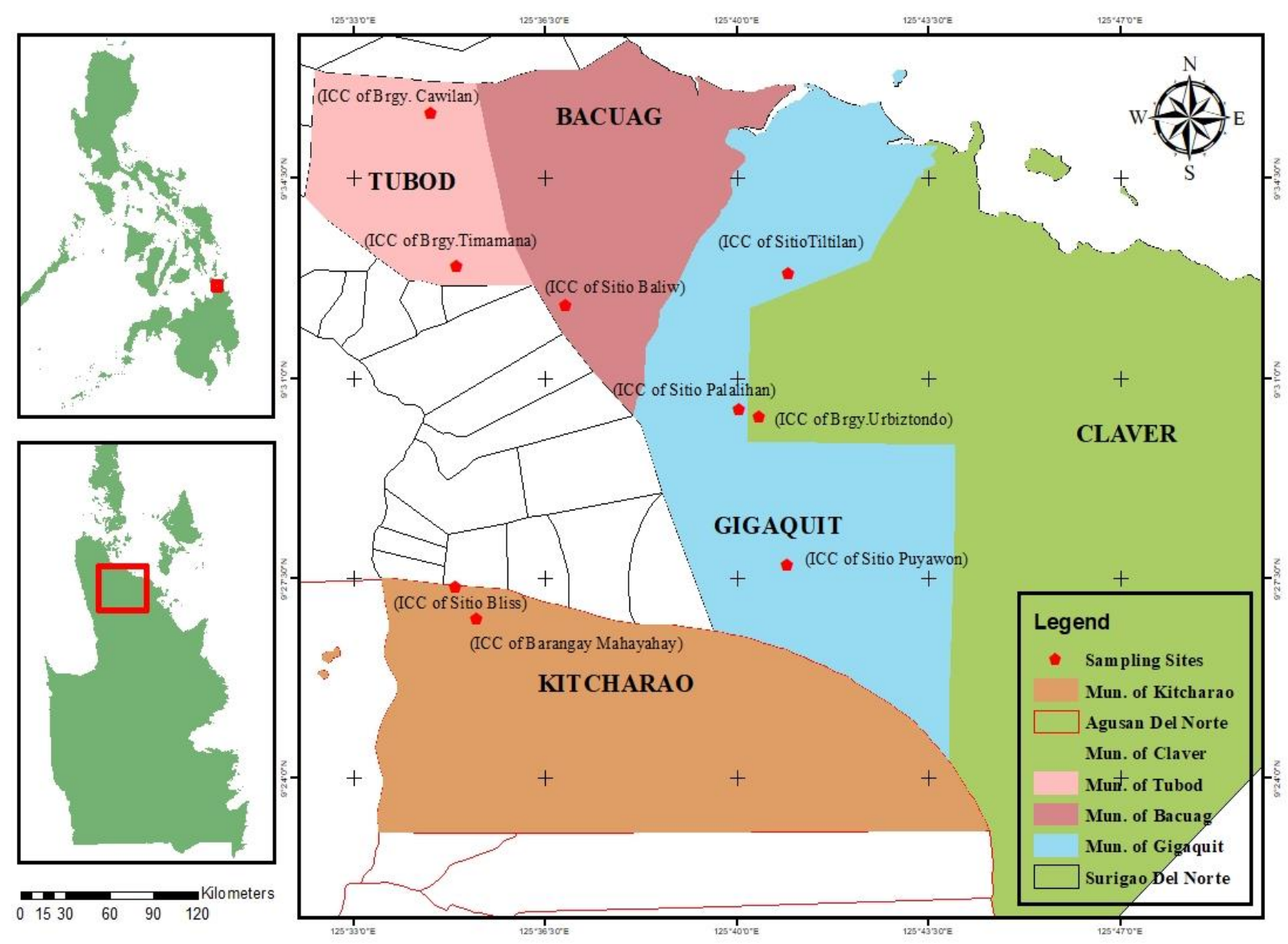

Figure 1. Location of the Mamanwa communities in Surigao del Norte and Agusan del Norte, Philippines indicating the sampling sites: ICC of Sitio Puyawon ( $9^{\circ} 32^{\prime} 50.2^{\prime \prime}$ N $125^{\circ} 40^{\prime} 56.6^{\prime \prime}$ E), ICC of Sitio Palalihan (9 $30^{\prime} 20^{\prime \prime} \mathrm{N} 125^{\circ} 40^{\prime} 24.4^{\prime \prime}$ E), ICC of Sitio Tiltilan

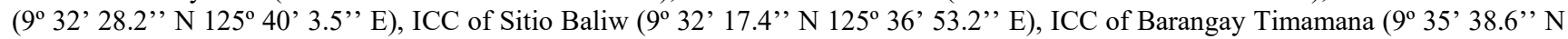
$125^{\circ} 34^{\prime} 25.2^{\prime \prime}$ E), ICC of Barangay Cawilan ( $9^{\circ} 32^{\prime} 58.4^{\prime \prime} \mathrm{N} 125^{\circ} 34^{\prime} 53.6^{\prime}$ ' E), ICC of Barangay Urbiztondo (9 $9^{\circ} 30^{\prime} 52^{\prime \prime} \mathrm{N} 125^{\circ} 52^{\prime}$

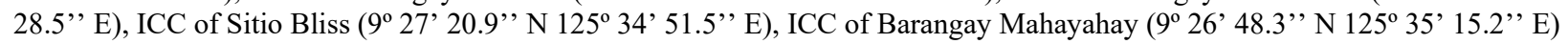

\section{Gratuitous permit}

Local permits secured from barangay chairpersons and municipal mayors were first secured as necessary requirements for the granting of a gratuitous permit. A gratuitous permit (WILDLIFE GP No. R13-2019-34) was obtained from the Department of Environment and Natural Resources (DENR) CARAGA Regional Office. The GP granted permission to the research team to conduct the survey and collect samples (medicinal plants) from the areas belonging to Certificate of Ancestral Domain Title (CADT) No. 048, subject to the terms, conditions and restrictions specified in the said GP pursuant to the provisions of Wildlife Resources Conservation and Protection Act of 2001 (Republic Act 9147).

\section{Interview and field sampling}

Data were obtained using informal interviews, semistructured questionnaires, and group conversations in the dialect (Cebuano, Bisaya) with the key informants, tribal members/local residents, male and female respondents, and traditional healers. Any form of videography was done in accordance with the FPIC and in the context of cultural sensitivity and vulnerability. Field excursion/walk with the traditional healers and herbal medicine collectors was carried out to observe the plants. Plant samples were collected together with the IP's to assure the identity of the plant. The collected plants were tagged and the details of the plants were recorded.

Demographic information such as age, gender, source of livelihood, educational status, dialect of respondents, and ethnobotanical knowledge (medicinal plants and its uses) were gathered. The interviews were developed as informal conversations in order to let the respondents speak spontaneously and to minimize, if not eliminate, the element of pressure. Elderly, "dakula" or "datus" (recognized head or community leader of the tribe), and "tambajon" or "babaylans" (local healers), identified by the "dakulas" or "datus" and other local people who have knowledge on medicinal plants were interviewed. In order to get a gender perspective, women especially mothers or wives were also interviewed. Data such as the medicinal plants used, the part/s of the plant used, the mode of local preparation, the mode of treatment, expected effects, and ailments treated were gathered. Moreover, traditional knowledge and 
practices in agriculture and spiritual aspect were also documented (if mentioned). Informal conversations were held to gather data on the status of medicinal plants and traditional medicinal knowledge of the community and their transferability from generation to generation (Martin 1995). This method assumes that there are variations in informants' opinions, experiences, and knowledge related to medicinal plants (Tumoro and Maryo 2016).

\section{Identification and preservation of plant specimens}

For the identification of medicinal plants, the books entitled A Dictionary of Philippine Plant Names Volume I (2001) and A Pictorial Cyclopedia of Philippine Ornamental Plants Second Edition (2000) written by Dr. Domingo Madulid, internet sources (taxonomic and pictorial keys) from legitimate sites such as www.philippineplants.org / Co's Digital Flora (Pelser et al. 2011 onwards), www.phytoimages.siu.edu (Nickrent et al. 2006 onwards), and www.stuartxchange.com (Stuart 2003 onwards) were used. Moreover, the method of Umair et al. (2017) on authenticating plant species was followed using the international plant name index (http://www.ipni.org) and GRIN taxonomy site (http://www.arsgrin.gov/cgibin.npgs/html/queries.pl), whereas names of plant families follow A.P.G. system (Stevens 2001). A botany professor and an expert on plant taxonomy at the Mindanao State University-Iligan Institute of Technology and a consultant from the University of the Philippines Los Baños identified the species and confirmed the identification. The species entries were complemented along with data on taxonomic position (family), vernacular name, common name, life form (plant habit), and folk medicinal uses. The life forms were categorized as herbs, shrubs, grasses, and trees, according to the system proposed by Raunkiaer $(1934,1937)$ and modified by Brown (1977).

Collected specimens were pressed using a wooden plant press, treated with denatured alcohol to avoid the growth of molds and fungi, dried, and prepared to be submitted as herbarium specimens. Three copies of plant samples were collected where 2 copies are deposited at the herbarium in the Mindanao State University-Iligan Institute of Technology and one copy will be deposited at the Philippine National Museum.

\section{RESULTS AND DISCUSSION}

\section{Demographic characteristics}

Demographic characteristics of the key informants from the 10 ICCs belonging to four municipalities of Surigao del Norte (Gigaquit, Claver, Bacuag, and Tubod) and one municipality of Agusan del Norte (Kitcharao) were gathered through informal interviews. A total of 142 respondents were interviewed wherein 30 or $21 \%$ are male and 112 or $79 \%$ are female. Mainly, there were more female informants than male informants in this study. This can be due to the fact that females are more available than males because females are usually left in the household while males are working in the farm or away from home. In terms of age, among the respondents, the age range of 3140 years old $(32 \%)$ has the highest frequency interviewed, followed by 21-30 years old (24\%), 41-50 years old (19\%), and 51-60 years old (14\%). As to marital status, $95 \%$ of the respondents are married while only $5 \%$ are single. From the ten ICCs, only 12 respondents have experienced being a traditional health practitioner. Of the 12 traditional health practitioners, four or $44 \%$ are male and eight or $67 \%$ are females. Similar finding was reported in the study of Tantengco et al. (2018) among the Ayta in Dinalupihan, Bataan wherein the report stated higher number of female informants than male because females were more available than males (Table 1).

\section{Plant species recorded}

In this ethnomedicinal survey, a total of 78 plants species (including two fern species) were documented as medicinal plants in the different Mamanwa communities visited by the research team in Sitio Puyawon, Sitio Tiltilan and Sitio Palalihan in Gigaquit, Surigao del Norte; Sitio Cawilan and Sitio Timamana in Tubod, Surigao del Norte; Sitio Urbiztondo and Sitio Taganito in Claver, Surigao Del Norte; Sitio Baliw in Bacuag, Surigao Del Norte; and Sitio Mahayahay and Sitio Bliss in Kitcharao, Agusan Del Norte. The plant families, scientific names, along with the plant habit of growth, common names/ English names and local/ Mamanwa names, plant part(s) used, modes of preparation and utilization, and medicinal plants are presented in Table $\mathrm{S} 1$.

Previous studies on medicinal plants used by the Mamanwa tribe conducted across different Mamanwainhabited areas in Mindanao are few and limited. The most recent study documenting the ethnomedicinal knowledge of Mamanwas was conducted by Demetillo et al. (2019) in selected mining area in Claver, Surigao del Norte, wherein it has documented a total of 51 plant species which was gathered from 29 respondents. Meanwhile, the study of Gruyal et al. (2014) documented 65 medicinal plants gathered from 50 informants in Northern, Surigao del Sur. To compare, the results in this ethnobotanical study have documented greater number of medicinal plant species. The greater number of medicinal plants documented can be attributed to greater number of respondents interviewed as well as wider coverage of the study. However, this can also indicate that the Mamanwa tribe in the selected study sites have managed to retain their traditional medicinal practices.

According to Yaseen et al. (2019), plant biodiversity is a potentially valuable source of novel drugs. The number of species distributed to different plant families presented in Table 2 shows a considerable diversity of medicinal plants. Among the plant families, Family Asteraceae (Compositae) held dominance among others having the highest number of species with 10 reported medicinal plants followed by Families Poaceae (Graminae), Lamiaceae, Annonaceae, and, Moraceae (with 4 species each), Families Amaryllidaceae, Fabaceae, Lauraceae, Rutaceae, and Zingiberaceae (with 3 species each) while the rest are represented by two or one species only. 
Table 1. Demographic profile of the respondents from Surigao del Norte and Agusan del Norte, Philippines

\begin{tabular}{|c|c|c|c|c|c|c|c|}
\hline \multirow{2}{*}{$\begin{array}{l}\text { Demographic } \\
\text { characteristics }\end{array}$} & \multicolumn{5}{|c|}{ Municipality } & \multirow[b]{2}{*}{ Total } & \multirow[b]{2}{*}{ Percentage $(\%)$} \\
\hline & Gigaquit & Bacuag & Tubod & Claver & Kitcharao & & \\
\hline Sex & \multicolumn{7}{|c|}{ Number of male and female informants } \\
\hline Male & 12 & 3 & 5 & 5 & 5 & 30 & $21 \%$ \\
\hline Female & 38 & 18 & 21 & 10 & 25 & 112 & $79 \%$ \\
\hline Total & 50 & 21 & 26 & 15 & 30 & 142 & $100 \%$ \\
\hline Age range & \multicolumn{7}{|c|}{ Number of respondents by age group } \\
\hline$\leq 20$ & 3 & 0 & 2 & 0 & 3 & 8 & $6 \%$ \\
\hline $21-30$ years & 17 & 0 & 4 & 4 & 10 & 35 & $24 \%$ \\
\hline $31-40$ years & 12 & 9 & 8 & 7 & 9 & 45 & $32 \%$ \\
\hline $41-50$ years & 4 & 12 & 5 & 3 & 3 & 27 & $19 \%$ \\
\hline $51-60$ years & 7 & 0 & 7 & 1 & 5 & 20 & $14 \%$ \\
\hline$\geq 61$ years & 7 & 0 & 0 & 0 & 0 & 7 & $5 \%$ \\
\hline Total & 50 & 21 & 26 & 15 & 30 & 142 & $100 \%$ \\
\hline Marital status & \multicolumn{7}{|c|}{ Number of respondents by marital status } \\
\hline Single & 2 & 1 & 2 & 0 & 2 & 7 & 5 \\
\hline Married & 48 & 20 & 24 & 15 & 28 & 135 & $95 \%$ \\
\hline Total & 50 & 21 & 26 & 15 & 30 & 142 & $100 \%$ \\
\hline Sex & \multicolumn{7}{|c|}{ Number of male and female herbalist } \\
\hline Male & 4 & 0 & 0 & 0 & 0 & 4 & $33 \%$ \\
\hline Female & 7 & 0 & 1 & 0 & 0 & 8 & $67 \%$ \\
\hline Total & 11 & 0 & 1 & 0 & 0 & 12 & $100 \%$ \\
\hline
\end{tabular}

Table 2. Over-all distribution of species across different families of medicinal plants used by the Mamanwa Tribe of Surigao del Norte and Agusan del Norte, the Philippines

\begin{tabular}{lc}
\hline Families & No. of species \\
\hline Acanthaceae & 2 \\
Amaryllidaceae & 3 \\
Anacardiaceae & 1 \\
Annonaceae & 4 \\
Apiaceae & 1 \\
Apocynaceae & 2 \\
Arecaceae & 1 \\
Asparagaceae & 1 \\
Asteraceae & 10 \\
Athyriaceae & 2 \\
Balsaminaceae & 1 \\
Bixaceae & 1 \\
Caricaceae & 1 \\
Commelinaceae & 1 \\
Crassulaceae & 1 \\
Cucurbitaceae & 1 \\
Cyperaceae & 1 \\
Dilleniaceae & 1 \\
Euphorbiaceae & 2 \\
Fabaceae & 3 \\
Lamiaceae & 4 \\
Lauraceae & 3 \\
Lecythidaceae & 1 \\
Lyrathaceae & 1 \\
Meliaceae & 1 \\
Menispermaceae & 1 \\
Moraceae & 1 \\
Moringaceae & 1 \\
Myrtaceae & 1 \\
Muntingaceae & 1 \\
Musaceae & 1 \\
Piperaceae & 1 \\
Poaceae & 1 \\
Rubiaceae & 1 \\
Rutaceae & 1 \\
Solanaceae & 1 \\
Urticaceae & 1 \\
Verbenaceae & 1 \\
Vitaceae & 1 \\
Zingeberaceae & 1 \\
Total & 1 \\
\hline & 1 \\
& 1 \\
\hline
\end{tabular}

Corresponding to this result, the study of Malawani et al. (2017) also documented the highest number of representatives from Family Asteraceae with seven recorded species. Asteraceae/Compositae having the most representative species can be attributed to the fact that it is one of the largest and most diverse of all plant families where it includes over 1,620 genera and 23,600 individual species (Tamokou et al. 2017). The case study on the usage of Family Asteraceae conducted in Saddah Lower Kurram Agency by Muhammad et al. (2016) affirms that this family is used by local communities to treat various human ailments. However, when compared to studies conducted by Fiscal (2017), Rubio and Naïve (2018), and Tantengco et al. (2018), plant families such as Euphorbiaceae, Fabaceae, Lamiaceae and Liliaceae have dominated in terms of species representation.

\section{Habit of growth}

On the data of the habit of growth, out of the 78 species, trees constituted the largest proportion with 32 plant species that cover $41 \%$, followed by herbs with 26 species (33\%), shrubs with 8 species (10\%), vines with 4 species (5\%), ferns with 2 species $(3 \%)$, and palm with 1 species (1\%) (Table 3).

Table 3. The habit of growth of medicinal plant species used by the Mamanwa Tribe Surigao del Norte and Agusan del Norte, the Philippines

\begin{tabular}{lcc}
\hline Habit of growth & \multicolumn{2}{c}{ Surigao Del Sur and Agusan del Norte } \\
\cline { 2 - 3 } & Number of plant species & Percentage (\%) \\
\hline Tree & 32 & $41 \%$ \\
Herb & 26 & $33 \%$ \\
Shrub & 8 & $10 \%$ \\
Grass & 5 & $6 \%$ \\
Vine & 4 & $5 \%$ \\
Fern & 2 & $3 \%$ \\
Palm & 1 & $1 \%$ \\
Total & 78 & $100 \%$ \\
\hline
\end{tabular}


Mamanwas are located in areas where trees are abundant. In fact, the term Mamanwa is etymologized from the word 'man' which means first and 'banwa' as forest thus, widely known as the first forest dwellers (Balacuit et al. 2018). Therefore, they mostly rely on trees in treating various diseases. Waay-Juico et al. (2017) on the Tagabawa tribe in Sta. Cruz, Davao del Sur, also reported the high usage of trees as medicinal plants which could be an indication that trees are abundant in the area as compared to other habit forms.

\section{Plant parts utilized as medicine}

Different plant parts were utilized for the preparation of herbal medicines, however, leaves were the most frequently used plant parts, constituting $46 \%$, followed by roots $(17 \%)$, fruit $(8 \%)$ whole plant $(7 \%)$, stem $(7 \%)$, bark $(6 \%)$, shoot $(4 \%)$, rhizome $(2 \%)$, bulb $(1 \%)$, sap $(1 \%)$, and hair (1\%) (Figure 2).

The high usage of leaves in making herbal medicines as compared to other plant parts is due to the reason that it is easier to collect and it poses lesser threat to the local flora. It indicated that the survival and continuity of useful medicinal plants of Surigao Del Norte are greatly maintained and protected by the Mamanwas in their use most of the leaves, thus, it ensures sustainable utilization of their medicinal plants. Several ethnobotanical surveys conducted in the Philippines reported similar results with leaves as the most frequently used plant parts. The use of leaves is common in ethnobotanical studies (Mahmood et al. 2011). Leaves have high storage of chemical compounds through photosynthesis which are active components of most herbal preparation in high concentrations (Guevara and Garcia 2018). According to Hamel et al. (2018), leaves are the site for the synthesis of secondary metabolites and the frequent usage of leaves can be justified by the abundant chemical groups they contain. In addition, the study of Khan et al. (2014) stated that the use of leaves is not detrimental to the plant life cycle as compared with using other plant parts such as the roots, flowers, etc., and reported that high utilization of leaves is due to its easy availability. Meanwhile, Baddu et al. (2018) also reported that leaves are the most utilized plant parts for medicinal purposes with 30 identified uses in curing illnesses among the Y' Apayaos of Sta. Praxedes, Cagayan Province. Olowa et al. (2012) also reported that the frequent use of leaves as compared to other plant parts in medicinal preparations indicated that the survival and continuity of useful medicinal plants in Rogongon is greatly maintained and protected by the Higaonons.

The roots were the second frequently used plant part used by the Mamanwas as body energizers or otherwise known as "talimughat". According to some informants, Mamanwas are known for the use of "talimughat" as body energizers. Before they were categorized as semi-settlers, they were usually seen on the streets selling "talimughat". However, the use of roots as herbal remedy is detrimental for the plants and the environment as well.

\section{Methods of preparation and mode of application}

The preparation and administration of the medicinal plants vary based on the type of disease treated. In this study, there were six types of methods of preparation recorded (Table 4). The most frequently employed preparation method was decoction $(40 \%)$, because it is the easiest way to prepare medicinal plants. Other methods of preparation were poultice $(18 \%)$, heating over fire $(14 \%)$, extract $(11 \%)$, raw $(10 \%)$, and infusion $(7 \%)$. Plant parts that were frequently prepared as decoction were leaves and roots and were mostly used to cure stomach pain, diarrhea, flatulence, cough, fever, and as body energizers. It was also recorded that the use of either bark or roots prepared as decoction was observed to be related to reproductive healthcare in women. For immediate treatments of cuts and wounds, leaves or the whole plant were pounded to create a poultice and applied directly to affected area. The result of the study is similar to the findings of Mapatac (2019) wherein decoction was the most employed method of preparation.

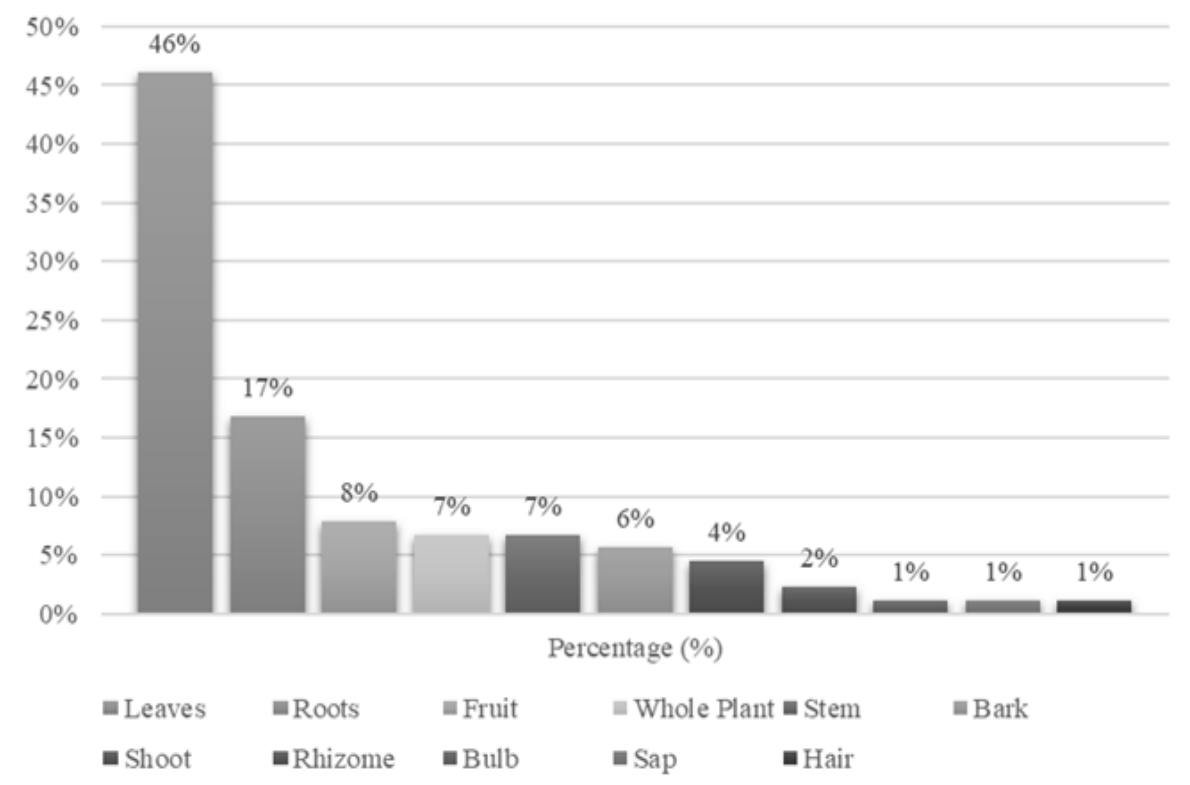

Figure 2. Plant parts used in herbal preparations by the Mamanwas of Surigao del Norte and Agusan del Norte, Philippines 
Table 4. Method of preparation of medicinal plants used by the Mamanwas of Surigao del Norte and Agusan del Norte, Philippines

\begin{tabular}{lcc}
\hline \multirow{2}{*}{$\begin{array}{l}\text { Method of } \\
\text { preparation }\end{array}$} & \multicolumn{2}{c}{ Surigao del Norte and Agusan del Norte } \\
\cline { 2 - 3 } Percentage (\%) \\
\hline Decoction & 35 & $40 \%$ \\
Poultice & 16 & $18 \%$ \\
Heated & 12 & $14 \%$ \\
Extract & 10 & $11 \%$ \\
Raw & 9 & $10 \%$ \\
Infusion & 6 & $7 \%$ \\
Total & 88 & $100 \%$ \\
\hline
\end{tabular}

Table 5. Mode of application of medicinal plants used by the Mamanwas of Surigao del Norte and Agusan del Norte, Philippines

\begin{tabular}{lcc}
\hline Mode of application & $\begin{array}{c}\text { Number of } \\
\text { applications }\end{array}$ & $\begin{array}{c}\text { Percentage } \\
(\%)\end{array}$ \\
\hline Taken orally & 45 & $52 \%$ \\
Directly applied to affected area & 41 & $47 \%$ \\
Wrapped on affected area & 1 & $2 \%$ \\
Total & 87 & $100 \%$ \\
\hline
\end{tabular}

As to mode of application, around $52 \%$ of the medicinal plants were taken orally. Forty-two percent of medicinal plants were directly applied to affected area and wrapped on affected area was only $1 \%$. (Table 5). The result is similar to the findings of other ethnobotanical surveys conducted in Dinalupihan Bataan (Tantengco et al 2018) and Subanens in Dumingag, Zamboanga Del Sur (Morilla et al 2014). Both previous studies documented that oral intake of decoction is the most common route of administration of medicinal plants.

To conclude, this study showed that the Mamanwa communities situated in selected ICC's of Surigao del Norte and Agusan del Norte in Mindanao, Philippines used a total of 78 plant species belonging to 70 genera and 42 families for medicinal purposes. This indicates that a diverse set of medicinal plants is utilized by the Mamanwas as herbal medicines. The Mamanwas have also managed to retain their traditional medicinal practices even nowadays due to their practical benefits, availability, and reliability in terms of providing primary aid and immediate remedy to address various common ailments and diseases. On the data on habit of growth, trees constituted the largest proportion comprising $41 \%$ of the plant species documented. In terms of plant parts used, leaves are the most frequently used. This indicates that the survival and continuity of useful medicinal plants of Surigao del Norte and Agusan del Norte are greatly maintained and protected by the Mamanwas in their use mostly of the leaves, thus, it ensures sustainability in the utilization of their medicinal plants. As to mode of utilization, the most frequently employed is decoction (40\%) because it is the easiest way to prepare the medicinal plants. Plant parts that are frequently prepared as decoction are leaves and roots and mostly used to cure stomach pain, diarrhea, flatulence, cough, fever and as body energizers.

\section{ACKNOWLEDGEMENTS}

The authors would like to acknowledge the Philippine Institute of Traditional and Alternative Health Care (PITAHC) for providing research funds, the Premier Research Institute of Science and Mathematics (PRISM) for the use of lab facilities, and the valuable help of Dr. William Sm. Gruezo and Jaime Guihawan for the identification of plant species.

\section{REFERENCES}

Aiyeloja AA, Bello OA. 2006. Ethnobotanical potentials of common herbs in Nigeria; a case study of Enugu state. Educ Res Rev 1 (1): 1622.

Alpuerto AFT, Bangaysiso A, Galang V, Maquiling L, Taylor, Ugat, GJ. 2010. Level of awareness and extent of utilization of the ten medicinal plants approved by the department of health. Nursing Res $\mathbf{J}$ 2 (1): 73-92.

Arquion CD, Nuñeza OM, Uy MM. 2015. Evaluating the potential cytotoxic activity of Ficus nota using brine shrimp lethality test. Bull Environ Pharmacol Life Sci 4 (12): 40-44.

Brown CH. 1977. Folk botanical life-forms: Their universality and growth. Am Anthropol 79 (2): 317-342. DOI: 10.1525/aa.1977.79.2.02a00080.

Balacuit Jr CV, Quezada EO, Abay-abay JL, Caluban JR, Cedron LP, Corvera LA, Cuadrado BM, Huerte APA, Montenegro GP, Portillo GA. 2018. Livelihood and training needs of Mamanwa tribe. Intl J Curr Res 10 (9): 73958-73954.

Banag-Moran CI, Bautista FA, Bonifacio KAM, De Guzman ML, Lim JL, Tandang DN, Dagamac. 2020. Variations in floristic composition and community structure between disturbed and undisturbed lowland forest in Aklan, Philippines. Geol Ecol Landscapes 1-10. DOI: 10.1080/24749508.1814187

Baddu VD, Oanu NB. 2018. Ethnobotanical survey of medicinal plants used by the Y'Apayaos of Sta. Praxedes in the Province of Cagayan, Philippines. Mindanao J Sci Technol 16 (2018): 128-153.

Cuyacot AR, Mahilum JJM, MRSB, Madamba. 2014. Cytotoxicity potentials of some medicinal plants in Mindanao, Philippines. Asian J Plant Sci Res 4 (1): 81-89.

Demetillo MT, Betco GL, Goloran AB. 2019. Assessment of native medicinal plants in selected mining area of Claver Surigao del Norte, Philippines. J Med Plants Stud 7 (2): 171-174.

Fiscal RR. 2017. Ethnomedicinal plants used by traditional healers in Laguna, Philippines. Asia Pac J Multidisciplinary Res 5 (4): 132-137.

Gaither MR, Rocha LA. 2013. Origins of species richness in the Indo-Malay-Philippine biodiversity hotspot: evidence for the centre of overlap hypothesis. J Biogeograph 40 (9): 1638-1648. DOI: 10.1111/jbi.12126

Gurrea LC. 1993. Morpho-histochemical studies of commonly used medicinal plants in Bukidnon. Trans Nat Acad Sci Technol 15: 153160.

Galvez-Tan JZ, Sia I. 2014. The best 100 Philippines medicinal plants. http://www.map-

abcdf.com.ph/documents/presentations/Countryside $\% 20$

Development/

Guevara CPB, Garcia MM. 2018. Ethnobotanical practices of Matigsalug tribe on medicinal plants at Barangay Baganihan, Marilog District, Davao City. J Complement Altern Med Res 6 (3): 1-14. DOI: 10.9734/JOCAMR/2018/43031

Gruyal AG, Roasario RD, Palmes ND. 2014. Ethnomedicinal plants used by residents in Northern Surigao del Sur, Philippines. Nat Prod Chem Res 2: 140. DOI:10.4172/2329-6839.1000140.

Heinrich M, Jager AK. 2015. Ethnopharmacology. John Wiley and Sons. 
Hamel T, Zaafourl M, Bourmendjel M. 2018. Ethnomedical knowledge and traditional uses of aromatic and medicinal plants of the Wetlands Complex of the Guerbes-Sanhadja Plain (Wilaya of Skikda in Northeastern Algeria). Herb Med 4 (1): 3. DOI: 10.21767/24720151.100035

Joven AE. 2012. Colonial adaptations in tropical Asia: Spanish medicine in the Philippines in the seventeenth and eighteenth centuries. International Christian University Publications, 3-A, Asian Cult Stud 171-186. https://core.ac.uk/download/pdf/234717762.pdf.

Khan I, AbdElsalam NM, Adnan M. 2014. Application of ethnobotanical indices on the use of traditional medicines against common diseases. Evid Based Complement Alternat Med 2012: 2014: 635371. DOI: $10.1155 / 2014 / 635371$

Keo S, Chrin B, Dim D, Buth B, Chea S, Chan R, So V, Meng C, Prak S. 2018. Ethnobotanical survey of medicinal plants used by traditional healers in Kampong Speu province, Cambodia. Asian J Pharmacog 2 (1): 21-32.

Martin GJ. 1995 Ethnobotany: A Methods Manual. Chapman and Hall, London.

http://dx.doi.org/10.1007/978-1-4615-2496-0.

Madulid DA. 2000. A Pictorial Cyclopedia of Philippine Ornamental Plants Second Edition. The Bookmark Inc., Makati City, Philippines.

Madulid DA. 2001. A Dictionary of Philippine Plant Names Volume I. The Bookmark Inc., Makati City, Philippines.

Majumdar K, Datta BK. 2007. A study on ethnomedicinal usage of plants among the folklore herbalists and Tripuri medicinal practitioners. Part 1. Nat Prod Rad 6 (1): 6-73.

Mahmood A, Qureshi R, Mahmood A, Sangi Y, Shashee H, Ahmad I, Nawaz Z. 2011. Ethnobotanical survey of common medicinal plants used by 44 people of district Mirpus, AJK, Pakistan. J Med Plants Res 5 (18): 4493-4498. DOI: 10.5897/JMPR11.1358

Maghanoy LGM, Rivero HI, Olowa LF, Aranico EC, NHN Sumaya 2013. Ethnomedicinal plants of the selected tribal communities in Sitio Sinaburan, Barangay Imbayao, Malaybalay City, Bukidnon Province, Philippines. 3rd International Congress on Interdisciplinary Research and Development. May 30-31, 2013, Thailand.

Malawani AD, Nuneza OM, Uy MM, Senarath WTPSK. 2017. Ethnobotanical survey of the medicinal plants used by the Maranaos in Pualas, Lanao del Sur Philippines. Bull Environ Pharmacol Life Sci 6 (6): $45-53$

Mapatac LC. 2019. Characterization of selected medicinal plants of Mamanwa tribe in Caraga, Philippines. Texila Int J Basic Med Sci 4 (1). DOI: 10.21522/TIJBMS.2016.04.01.Art005

Morilla DA, Rivero NHN, Madamba MRSB. 2014. Medicinal plants of the Subanens in Dumingag, Zamboanga del Sur, Philippines. International Conference on Food, Biological and Medical Science. Bangkok, Thailand.

Muhammad S, Hussain M, Rahman IU, Shah GM, Ijaz F, Ullah K. 2016. Indigenous medicinal usage of family Asteraceae in Sadda Lowe Kurram Agency; a case study. Asian J Sci Technol 7 (12): 3998-4003.

Nickrent DL, Costea M, Barcelona JF, Pelser PB, Nixon K. 2006 onwards. Phytoimages. http://www.phytoimages.siu.edu

Olowa LF, Torres MAJ, Aranico EC, Demayo CG. 2012. Medicinal plants used by the Higaonon Tribe of Rogongon, Iligan City, Mindanao, Philippines. Adv Environ Biol 6 (4): 1442-1449

Patil HM. 2012. Ethnobotanical notes on Satpura Hills of Nandurbar District, Maharashtra, India. Res J Recent Sci 1: 326-328.

Pelser PB, Barcelona JF, Nickrent DL. 2011 onwards. Co's Digital Flora of the Philippines. www.philippineplants.org
Quisumbing EE. 1978. Medicinal Plants of the Philippines. Katha Publishing Co. Inc. Q.C.

Raunkiaer C.1934. The life forms of plants and statistical plant geography. Oxford: Clarendon Press.

Rubio MM, Naïve MA. 2018. Ethnomedicinal plants used by traditional healers in North Cotabato, Mindanao, Philippines. J Biodivers Environ Sci 13 (6): 74-82.

Stevens PF. 2001 onwards. Angiosperm Phylogeny Website Version 12, July 2012

Stuart G. 2003. The Complete Updated List of Philippine Medicinal Plants in Tagalog and English. www.stuartxchange.org (onwards)

Soejarto DD, Southayong B, Sydar K, Bouamanivong S, Riley MC, Libman A, Kadushin MR, Gyleenhaal C. 2009. A collaborative program between the University of Illinois at Chicago (UIC) and the Traditional Medicine Research Center (TMRC), Lao PDR: Accomplishments. Research on Development, Culture, Language, and Traditional Medicine, Contemporary Lao Studies.

Sharmila M, Rajeswari M, Jayashree I, Tamizharas K. 2018. Survey of some plants in Nainamalai Foothill, Eastern Ghats, Namakkal. Asian $\begin{array}{lllll}\text { J Pharm Clini Res } 11 & \text { (10): 69-77. DOI: }\end{array}$ 10.22159/ajpcr.2018.v11i10.25097

Trono D, Nuñeza OM, Uy MM, Senarath WTPSK. 2016. In vitro alphaamylase and antioxidant activities of bark extracts of charcoal tree (Trema orientalis Linn). Int J Biosci 8 (1): 33-46. DOI: $10.12692 / \mathrm{ijb} / 8.1 .33-46$

Tumoro G, Maryo M. 2016. "Determination of Informant Consensus Factor and Fidelity Level of ethnomedicinal plants used by Misha Woreda, Hadiya Zone, Southern Ethiopia. Int J Biodivers Conserv 8 (12): 351-364. DOI: 10.5897/IJBC2016.1020

Tamokou JDD, Mbaveng AT, Kuete V. 2017. Antimicrobial activities of African medicinal spices and vegetables. Therapeutic Potential Against Metabolic, Inflammatory, Infectious, and Systemic Diseases. Academic Press.

Tantengco OAG, Condes MLC, Estadilla HHT, Ragragio EM. 2018. Ethnobotanical survey of medicinal plants used by Ayta Communities in Dinalupihan, Bataan, Philippines. Pharmacog J 10 (5). DOI: 10.5530/pj.2018.5.145

Taek MM, Pragojo B, Agil M. 2018. Ethnomedicinal plants used for the treatment of malaria in Malaka, West Timor. J Young Pharm 10 (2): 187. DOI: $10.5530 /$ jyp. 2018.10 .42

Umair M, Altaf M, Abbasi AM. 2017. An ethnobotanical survey of indigenous medicinal plants in Hafizabad district, Punjab-Pakistan. PLoS ONE12 (6): e0177912. DOI: 10.1371/journal.pone.0177912.

World Health Organization (WHO). 2005. National Policy on Traditional Medicine and Regulation of Herbal Medicines. Geneva: Report of WHO global survey.

Waay-Juico MC, Cortuna GE, Evangelista SHM, Gatal RRD, Licuanan CIKS, Tapia FJC. 2017. Ethnobotanical practices of Tagabawa Tribe on selected medicinal plants at Barangay Jose Rizal, Sta. Cruz Davao del Sur, Philippines. J Complement Altern Med Res 4 (3): 1-12. DOI: 10.9734/JOCAMR/2017/38301

Yaseen GM, Shinwari DP, Zafar M, Zhang G, Shinwari ZK, Sultana S. 2019. Medicinal plant diversity used for livelihood of public health in deserts and arid region of Sindh-Pakistan. Pak J Bot 2 (31): 24092419. DOI: 10.30848/PJB2019-2(31)

Zain-ul-Abidin S, Khan R, Ahmad M, Bhatti MZ, Zafar M, Saeed A. Khan N. 2018. Ethnobotanical survey of highly effective medicinal plants and phototherapies to treat diabetes mellitus II in South-West Pakistan. Indian J Tradit Knowledge 17 (4): 682-690. 
Table S1. Medicinal plants used by the Mamanwa Tribe of Surigao del Norte and Agusan del Norte, Philippines

\begin{tabular}{|c|c|c|c|c|c|c|}
\hline $\begin{array}{l}\text { Family/scientific } \\
\text { name }\end{array}$ & $\begin{array}{l}\text { Common } \\
\text { name }\end{array}$ & $\begin{array}{l}\text { Mamanwa } \\
\text { name }\end{array}$ & $\begin{array}{l}\text { Habit } \\
\text { of } \\
\text { growth }\end{array}$ & $\begin{array}{l}\text { Plant } \\
\text { parts } \\
\text { used }\end{array}$ & $\begin{array}{l}\text { Preparation and mode of } \\
\text { utilization }\end{array}$ & $\begin{array}{l}\text { Medicinal } \\
\text { application }\end{array}$ \\
\hline \multicolumn{7}{|l|}{ SPERMATOPHYTA } \\
\hline \multicolumn{7}{|l|}{ Acanthaceae } \\
\hline $\begin{array}{l}\text { Justicia gendarussa } \\
\text { Burm.f. }\end{array}$ & $\begin{array}{l}\text { Willow- } \\
\text { leaved } \\
\text { Justicia }\end{array}$ & Bangon-bangon & Herb & Leaves & $\begin{array}{l}\text { Boil in water and drink the } \\
\text { decoction; pound leaves and } \\
\text { applies topically on affected } \\
\text { area to serve as poultice }\end{array}$ & $\begin{array}{l}\text { Heals sprain and dislocated } \\
\text { bones }\end{array}$ \\
\hline \multirow[t]{2}{*}{$\begin{array}{l}\text { Hemigraphis } \\
\text { alternata (Burm.f.) } \\
\text { T. Anderson. }\end{array}$} & $\begin{array}{l}\text { Purple } \\
\text { waffle plant }\end{array}$ & Baylas & Herb & Fruit & $\begin{array}{l}\text { Pound fruit and directly apply } \\
\text { to affected area to serve as } \\
\text { poultice }\end{array}$ & Relieves pain during childbirth \\
\hline & & & & Leaves & $\begin{array}{l}\text { Pound until thoroughly soft, } \\
\text { squeeze to obtain extract and } \\
\text { drop some onto the affected } \\
\text { area }\end{array}$ & Wound healing \\
\hline \multicolumn{7}{|l|}{ Amaryllidaceae } \\
\hline \multirow[t]{3}{*}{$\begin{array}{l}\text { Allium ascalonicum } \\
\text { L. }\end{array}$} & Shallots & Sibujin & Herb & Leaves & $\begin{array}{l}\text { Heat over fire and apply } \\
\text { directly on affected area }\end{array}$ & Inflammation \\
\hline & & & & & $\begin{array}{l}\text { Squeeze the leaves very well, } \\
\text { add some salt and massage } \\
\text { onto the body }\end{array}$ & $\begin{array}{l}\text { Cure for convulsions or } \\
\text { "apresiya" among children }\end{array}$ \\
\hline & & & & & $\begin{array}{l}\text { Pound until thoroughly soft } \\
\text { and massage onto the body or } \\
\text { stomach }\end{array}$ & Relieves stomachache \\
\hline \multirow[t]{2}{*}{ Allium sativum $\mathrm{L}$. } & Garlic & Ahos & Herb & Bulb & $\begin{array}{l}\text { Pound and apply directly on } \\
\text { affected area }\end{array}$ & $\begin{array}{l}\text { Inflammation; cures venom } \\
\text { obtained from snake bites, dog } \\
\text { bites and "uhipan" (centipede) }\end{array}$ \\
\hline & & & & & $\begin{array}{l}\text { Pound until thoroughly soft } \\
\text { and massage onto the body or } \\
\text { stomach }\end{array}$ & Relieves stomachache \\
\hline $\begin{array}{l}\text { Allium tuberosum } \\
\text { Rottler ex. Spreng }\end{array}$ & Chives & Ganda & Herb & Leaves & $\begin{array}{l}\text { Heat over fire and apply } \\
\text { directly on affected area }\end{array}$ & $\begin{array}{l}\text { Heals fractures and dislocation; } \\
\text { treats rheumatism, arthritis; aids } \\
\text { to provide comfort when an } \\
\text { individual is having difficulty } \\
\text { when breathing; treats } \\
\text { convulsion }\end{array}$ \\
\hline \multicolumn{7}{|l|}{ Anacardiaceae } \\
\hline Mangifera indica $\mathrm{L}$. & Mango & Mangga & Tree & Fruit & $\begin{array}{l}\text { Cut fruit and eat the fleshy } \\
\text { part }\end{array}$ & Treats diarrhea \\
\hline \multicolumn{7}{|l|}{ Annonaceae } \\
\hline \multirow[t]{4}{*}{ Annona muricata $\mathrm{L}$. } & Soursop & Rabana & Tree & Leaves & $\begin{array}{l}\text { Boil in water and drink } \\
\text { decoction three times a day }\end{array}$ & Relieves cough \\
\hline & & & & & $\begin{array}{l}\text { Heat over fire and place it on } \\
\text { the affected area }\end{array}$ & Heals wound \\
\hline & & & & $\begin{array}{l}\text { Young } \\
\text { shoot }\end{array}$ & Massage on the back & $\begin{array}{l}\text { Provides relief in asthmatic } \\
\text { children }\end{array}$ \\
\hline & & & & Roots & $\begin{array}{l}\text { Prepare a decoction by } \\
\text { boiling and then consume } \\
\text { orally as a drink }\end{array}$ & Treats UTI \\
\hline $\begin{array}{l}\text { Annona squamosa } \\
\text { L. }\end{array}$ & Sugar apple & Atis & Tree & Leaves & Put on aching body parts & $\begin{array}{l}\text { Relief from muscle strain and } \\
\text { "pi-ang" or dislocation }\end{array}$ \\
\hline $\begin{array}{l}\text { Orophea sericea } \\
\text { Keb. }\end{array}$ & N/A & Panwahut & Tree & Roots & $\begin{array}{l}\text { Boil in water and drink } \\
\text { decoction }\end{array}$ & Relieves fatigue \\
\hline $\begin{array}{l}\text { Polyalthia } \\
\text { dolichophylla Merr. } \\
\text { Apiaceae }\end{array}$ & N/A & Hamutan & Tree & Roots & $\begin{array}{l}\text { Boil in water and drink } \\
\text { decoction }\end{array}$ & Relieves fatigue and headache \\
\hline \multirow[t]{2}{*}{$\begin{array}{l}\text { Centella asiatica } \\
\text { (L.) Urb. }\end{array}$} & Gotu kola & $\begin{array}{l}\text { Jahong-jahong or } \\
\text { Yahong-yahong }\end{array}$ & Herb & $\begin{array}{l}\text { Leaves } \\
\text { and stem }\end{array}$ & $\begin{array}{l}\text { Put in a glass of water and } \\
\text { drink infused water three } \\
\text { times a day }\end{array}$ & $\begin{array}{l}\text { Stomachache, } \\
\text { Amoeba, measles }\end{array}$ \\
\hline & & & & & $\begin{array}{l}\text { Put in a glass of water } \\
\text { together with "busikad" plant } \\
\text { and drink }\end{array}$ & $\begin{array}{l}\text { Helps in treating measles by } \\
\text { making them appear or } \\
\text { according to the term locals } \\
\text { used "para mulutaw ang tipdas" }\end{array}$ \\
\hline
\end{tabular}




\begin{tabular}{|c|c|c|c|c|c|c|}
\hline \multicolumn{7}{|l|}{ Apocynaceae } \\
\hline \multirow[t]{2}{*}{$\begin{array}{l}\text { Alstonia scholaris } \\
\text { (L.) R.Br. }\end{array}$} & \multirow[t]{2}{*}{$\begin{array}{l}\text { White } \\
\text { cheese } \\
\text { wood }\end{array}$} & \multirow[t]{2}{*}{ Dita or Lita } & \multirow[t]{2}{*}{ Tree } & \multirow[t]{2}{*}{ Bark } & $\begin{array}{l}\text { Pound the bark to obtain } \\
\text { extract and apply directly on } \\
\text { the affect area }\end{array}$ & $\begin{array}{l}\text { Hernia or } \\
\text { "danlak" }\end{array}$ \\
\hline & & & & & $\begin{array}{l}\text { Prepare a decoction by } \\
\text { boiling and then consume } \\
\text { orally as a drink }\end{array}$ & $\begin{array}{l}\text { Treats vomiting and loose } \\
\text { bowel movement }\end{array}$ \\
\hline $\begin{array}{l}\text { Plumeria acuminata } \\
\text { Air. }\end{array}$ & $\begin{array}{l}\text { Temple } \\
\text { flower }\end{array}$ & Kalachuchi & Tree & Leaves & $\begin{array}{l}\text { Pound the leaves and apply } \\
\text { topically on affected area to } \\
\text { serve as poultice }\end{array}$ & Herpes simplex \\
\hline \multicolumn{7}{|l|}{ Arecaceae } \\
\hline \multirow[t]{2}{*}{ Calamus sp. } & \multirow[t]{2}{*}{$\begin{array}{l}\text { Rattan } \\
\text { (uway) }\end{array}$} & \multirow[t]{2}{*}{ Kayapi } & \multirow[t]{2}{*}{ Palm } & Fruit & $\begin{array}{l}\text { Pound fruit and directly apply } \\
\text { to affected area to serve as } \\
\text { poultice }\end{array}$ & $\begin{array}{l}\text { Acts as "talimughat" by } \\
\text { relieving pain during childbirth }\end{array}$ \\
\hline & & & & Roots & $\begin{array}{l}\text { Prepare a decoction by } \\
\text { boiling the roots and then } \\
\text { consume orally as a drink }\end{array}$ & $\begin{array}{l}\text { According to locals, this is } \\
\text { taken in order to avoid or } \\
\text { prevent getting pregnant }\end{array}$ \\
\hline \multicolumn{7}{|l|}{ Asparagaceae } \\
\hline $\begin{array}{l}\text { Sansevieria } \\
\text { roxburghiana } \\
\text { Schult.f }\end{array}$ & Bow string & $\begin{array}{l}\text { Espada or } \\
\text { Tigre-tigre }\end{array}$ & Herb & $\begin{array}{l}\text { Whole } \\
\text { plant }\end{array}$ & $\begin{array}{l}\text { Pound and apply directly on } \\
\text { affected area to serve as } \\
\text { poultice }\end{array}$ & $\begin{array}{l}\text { Eliminate venom due to snake } \\
\text { bite }\end{array}$ \\
\hline \multicolumn{7}{|c|}{ Asteraceae (Compositae) } \\
\hline $\begin{array}{l}\text { Ageratum } \\
\text { conyzoides } \mathrm{L} \text {. }\end{array}$ & $\begin{array}{l}\text { Billygoat } \\
\text { Weed }\end{array}$ & Albahaka & Herb & Leaves & $\begin{array}{l}\text { Pound to obtain extract and } \\
\text { apply directly to affected area } \\
\text { Pound leaves into smaller } \\
\text { pieces and rub or massage on } \\
\text { the chest or back }\end{array}$ & Relieves headache and migraine \\
\hline $\begin{array}{l}\text { Artemisia capillaris } \\
\text { Thnb. }\end{array}$ & $\begin{array}{l}\text { Oriental } \\
\text { wormwood }\end{array}$ & $\begin{array}{l}\text { Bino-bino or } \\
\text { Pikasin }\end{array}$ & Shrub & Roots & $\begin{array}{l}\text { Pound roots, squeeze extract } \\
\text { and rub or massage on to the } \\
\text { different parts of the body }\end{array}$ & Insect repellent \\
\hline $\begin{array}{l}\text { Artemisia vulgaris } \\
\text { L. }\end{array}$ & Mugwort & Hilbas & Herb & $\begin{array}{l}\text { Leaves } \\
\text { and stem }\end{array}$ & $\begin{array}{l}\text { Rub or massage on the chest } \\
\text { and back the pounded leaves } \\
\text { and stem }\end{array}$ & $\begin{array}{l}\text { Fever; relieves cough and } \\
\text { discomfort caused by sticky } \\
\text { phlegm cough }\end{array}$ \\
\hline $\begin{array}{l}\text { Ayapana triplinervis } \\
\text { (Vahl) R.M. King \& } \\
\text { H. Rob }\end{array}$ & $\begin{array}{l}\text { Triplinerved } \\
\text { Eupatorium }\end{array}$ & Magjupana & Herb & Leaves & $\begin{array}{l}\text { Pound the leaves and apply } \\
\text { topically on the affected area } \\
\text { to serve as poultice }\end{array}$ & Fever \\
\hline \multirow[t]{2}{*}{$\begin{array}{l}\text { Blumea balsamifera } \\
\text { (L.) DC. }\end{array}$} & \multirow[t]{2}{*}{$\begin{array}{l}\text { Ngai } \\
\text { camphor }\end{array}$} & \multirow[t]{2}{*}{ Sagbong } & \multirow[t]{2}{*}{ Shrub } & Leaves & $\begin{array}{l}\text { Boil in water and drink } \\
\text { decoction four times to } \\
\text { induce urination }\end{array}$ & Kidney infection \\
\hline & & & & Roots & $\begin{array}{l}\text { Boil in water and drink } \\
\text { decoction before eating meal }\end{array}$ & $\begin{array}{l}\text { "punit"; To avoid getting } \\
\text { pregnant }\end{array}$ \\
\hline $\begin{array}{l}\text { Cosmos sulpherus } \\
\text { Cav. }\end{array}$ & Cosmos & Cosmos & Herb & Leaves & $\begin{array}{l}\text { Heat over fire and directly } \\
\text { apply on affected area }\end{array}$ & Relieves abdominal pain \\
\hline $\begin{array}{l}\text { Chromolaena } \\
\text { odorata (L.) R.M. } \\
\text { King \& H. Rob. }\end{array}$ & Devil weed & Hagonoy & Herb & Leaves & $\begin{array}{l}\text { Heat over fire and directly } \\
\text { apply on affected area }\end{array}$ & $\begin{array}{l}\text { Relief from stomachache and } \\
\text { flatulence }\end{array}$ \\
\hline $\begin{array}{l}\text { Crassocephalum } \\
\text { crepidiodes (Benth.) } \\
\text { S. Moore. }\end{array}$ & $\begin{array}{l}\text { Red flower } \\
\text { Ragleaf }\end{array}$ & Taba-taba & Herb & Shoot & $\begin{array}{l}\text { Boil in water and drink } \\
\text { decoction }\end{array}$ & $\begin{array}{l}\text { Relieves fatigue, stomachache, } \\
\text { ulcer }\end{array}$ \\
\hline $\begin{array}{l}\text { Elephantopus } \\
\text { scaber } \mathrm{L} .\end{array}$ & $\begin{array}{l}\text { Elephant's } \\
\text { foot }\end{array}$ & Kukug banog & Herb & Roots & $\begin{array}{l}\text { Put roots in a glass of water } \\
\text { and drink the infused water }\end{array}$ & Treats measles \\
\hline Tagetes erecta $\mathrm{L}$. & Marigold & Alahito & Herb & Leaves & $\begin{array}{l}\text { Rub or massage on the chest } \\
\text { and back the pounded leaves } \\
\text { to relieve discomfort }\end{array}$ & Relieves fatigue \\
\hline \multicolumn{7}{|l|}{ Balsaminaceae } \\
\hline $\begin{array}{l}\text { Impatiens balsamina } \\
\text { L. }\end{array}$ & $\begin{array}{l}\text { Garden } \\
\text { balsam or } \\
\text { Kamantigue }\end{array}$ & Sarungga & Herb & Leaves & $\begin{array}{l}\text { Boil in water and drink } \\
\text { decoction four times a day to } \\
\text { induce urination }\end{array}$ & Kidney infection \\
\hline \multicolumn{7}{|l|}{ Bixaceae } \\
\hline \multirow[t]{2}{*}{ Bixa orellana L. } & \multirow[t]{2}{*}{ Annato } & \multirow[t]{2}{*}{ Syotis or Switis } & \multirow[t]{2}{*}{ Tree } & Leaves & $\begin{array}{l}\text { Heat over fire and directly } \\
\text { apply on affected area }\end{array}$ & Heals sprain \\
\hline & & & & Roots & $\begin{array}{l}\text { Boil in water and drink } \\
\text { decoction thrice a day to } \\
\text { soften cough }\end{array}$ & Cures cough \\
\hline \multicolumn{7}{|l|}{ Caricaceae } \\
\hline Carica papaya $\mathrm{L}$ & Papaya & Kapayas & Shrub & Leaves & $\begin{array}{l}\text { Boil in water and drink } \\
\text { decoction }\end{array}$ & Dengue \\
\hline
\end{tabular}




\begin{tabular}{|c|c|c|c|c|c|c|}
\hline $\begin{array}{l}\text { Commelinaceae } \\
\text { Amischotolype } \\
\text { hispida (Less. \& A. } \\
\text { Rich.) D.Y. Hong }\end{array}$ & $\begin{array}{l}\text {-No } \\
\text { common } \\
\text { name found- }\end{array}$ & Lupo-lupo & Herb & $\begin{array}{l}\text { Leaves, } \\
\text { stem }\end{array}$ & $\begin{array}{l}\text { Heat over fire and directly } \\
\text { place on affected area }\end{array}$ & Heals fracture and dislocation \\
\hline \multicolumn{7}{|l|}{ Crassulaceae } \\
\hline \multirow[t]{2}{*}{$\begin{array}{l}\text { Kalanchoe pinnata } \\
\text { (Lam.) Pers. }\end{array}$} & Miracle leaf & Hanlilika & Herb & Leaves & $\begin{array}{l}\text { Put leaves on the affected } \\
\text { area }\end{array}$ & Treats mumps \\
\hline & & & & & $\begin{array}{l}\text { Pound leaves into pieces and } \\
\text { apply on affected area }\end{array}$ & Relieves pain during toothache \\
\hline \multicolumn{7}{|l|}{ Cucurbitaceae } \\
\hline $\begin{array}{l}\text { Momordica } \\
\text { charantia } \mathrm{L} \text {. }\end{array}$ & Bitter gourd & Ampalaya & Vine & Leaves & $\begin{array}{l}\text { Boil in water and drink } \\
\text { decoction squeeze leaves and } \\
\text { obtain extract to drink }\end{array}$ & $\begin{array}{l}\text { Cleanse the stomach and treats } \\
\text { diarrhea helps expel worms in } \\
\text { babies }\end{array}$ \\
\hline \multicolumn{7}{|c|}{ 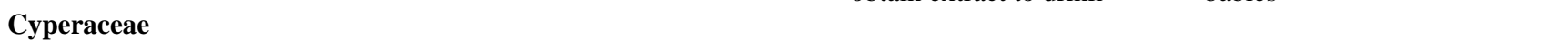 } \\
\hline $\begin{array}{l}\text { Cyperus kyllingia } \\
\text { Endl. }\end{array}$ & $\begin{array}{l}\text { Whitehead } \\
\text { Spikehedge }\end{array}$ & Busikad & Grass & $\begin{array}{l}\text { Whole } \\
\text { plant }\end{array}$ & $\begin{array}{l}\text { Boil in water and drink } \\
\text { decoction }\end{array}$ & Diarrhea, measles \\
\hline \multicolumn{7}{|l|}{ Dilleniaceae } \\
\hline $\begin{array}{l}\text { Dillenia } \\
\text { philippinensis Rolfe }\end{array}$ & Katmon & Maragnaw & Tree & Bark & $\begin{array}{l}\text { Boil in water and drink } \\
\text { decoction }\end{array}$ & Heals wound, cures diarrhea \\
\hline \multicolumn{7}{|l|}{ Euphorbiaceae } \\
\hline \multirow[t]{2}{*}{ Euphorbia hirta L. } & $\begin{array}{l}\text { Asthma } \\
\text { weed }\end{array}$ & Tawa-tawa & Herb & $\begin{array}{l}\text { Whole } \\
\text { plant }\end{array}$ & $\begin{array}{l}\text { Boil in water and drink } \\
\text { decoction three times a day }\end{array}$ & Dengue fever \\
\hline & & & & Stem & $\begin{array}{l}\text { Squeeze to obtain sap and use } \\
\text { as eye drops }\end{array}$ & Soothes sore eyes \\
\hline Jatropha curcas $\mathrm{L}$. & Physic nut & Tuba-tuba & Shrub & $\begin{array}{l}\text { Leaves } \\
\text { and } \\
\text { Stem }\end{array}$ & $\begin{array}{l}\text { Heat over fire and directly } \\
\text { apply on affected area }\end{array}$ & Relieves muscle pain \\
\hline \multicolumn{7}{|l|}{ Fabaceae } \\
\hline $\begin{array}{l}\text { Caesalpinia sappan } \\
\text { L. }\end{array}$ & $\begin{array}{l}\text { Sappan } \\
\text { wood }\end{array}$ & Sibukaw & Tree & Roots & $\begin{array}{l}\text { Boil in water and drink } \\
\text { decoction }\end{array}$ & $\begin{array}{l}\text { Urinary Tract Infection (UTI), } \\
\text { coughing with blood "sugpa" }\end{array}$ \\
\hline $\begin{array}{l}\text { Gliricidium sepium } \\
\text { (Jacq.) Walp. }\end{array}$ & $\begin{array}{l}\text { Madre de } \\
\text { cacao }\end{array}$ & $\begin{array}{l}\text { Kakwate or } \\
\text { Madre de kakaw }\end{array}$ & Tree & Leaves & $\begin{array}{l}\text { Pound leaves and apply } \\
\text { directly to affected area }\end{array}$ & Relieves skin itchiness \\
\hline $\begin{array}{l}\text { Phanera integrifolia } \\
\text { (Roxb.) Benth. }\end{array}$ & $\begin{array}{l}\text {-No } \\
\text { common }\end{array}$ & $\begin{array}{l}\text { Buka- } \\
\text { buka/alibangbang }\end{array}$ & Vine & $\begin{array}{l}\text { Leaves, } \\
\text { roots }\end{array}$ & $\begin{array}{l}\text { Boil in water and drink } \\
\text { decoction }\end{array}$ & Coughing with blood "sugpa" \\
\hline \multicolumn{7}{|l|}{ Lamiaceae } \\
\hline $\begin{array}{l}\text { Gmelina arborea } \\
\text { Roxb. }\end{array}$ & Yemane & Gemelina & Tree & Leaves & $\begin{array}{l}\text { Obtain some fresh leaves and } \\
\text { massage or place onto the } \\
\text { body }\end{array}$ & $\begin{array}{l}\text { Treats flatulence or "panuhot"; } \\
\text { heals rheumatism and } \\
\text { dislocation }\end{array}$ \\
\hline Mentha arvensis $\mathrm{L}$. & $\begin{array}{l}\text { Peppermint } \\
\text { or wild mint }\end{array}$ & Herba buena & Herb & Leaves & $\begin{array}{l}\text { Boil in water and drink } \\
\text { decoction thrice a day }\end{array}$ & Stomachache \\
\hline $\begin{array}{l}\text { Plectranthus } \\
\text { amboinicus (Lour.) } \\
\text { Spreng. }\end{array}$ & Oregano & $\begin{array}{l}\text { Kalabo or } \\
\text { Karabo }\end{array}$ & Herb & Leaves & $\begin{array}{l}\text { Pound, squeeze to obtain } \\
\text { extract, mix with "agridulsi" } \\
\text { (lemon) and take one } \\
\text { tablespoon three times a day }\end{array}$ & Cough relief \\
\hline Vitex negundo $\mathrm{L}$. & $\begin{array}{l}\text { Five-leaved } \\
\text { Chaste tree }\end{array}$ & Lagundi & Tree & Leaves & $\begin{array}{l}\text { Put in a glass of water and } \\
\text { drink }\end{array}$ & Relief from cough \\
\hline \multicolumn{7}{|l|}{ Lauraceae } \\
\hline $\begin{array}{l}\text { Cinnamomum } \\
\text { mindanaense Elmer. }\end{array}$ & $\begin{array}{l}\text { Kalingag } \\
\text { tree }\end{array}$ & Kaningag & Tree & Leaves & $\begin{array}{l}\text { Boil in water and drink } \\
\text { decoction }\end{array}$ & $\begin{array}{l}\text { Treats stomachache, ulcer, high } \\
\text { blood pressure }\end{array}$ \\
\hline \multirow[t]{2}{*}{ Litsea ampla Merr. } & $\begin{array}{l}\text { No common } \\
\text { name found }\end{array}$ & Panamog & Tree & Leaves & $\begin{array}{l}\text { Boil in water and drink } \\
\text { decoction }\end{array}$ & $\begin{array}{l}\text { Coughing with blood } \\
\text { "sugpa" }\end{array}$ \\
\hline & & & & Roots & $\begin{array}{l}\text { Boil in water, set to cool and } \\
\text { use as antiseptic wash }\end{array}$ & Disinfects wound \\
\hline $\begin{array}{l}\text { Persea Americana } \\
\text { Mill. }\end{array}$ & Avocado & Abukado & Tree & Leaves & $\begin{array}{l}\text { Boil in water and drink } \\
\text { decoction three times a day }\end{array}$ & $\begin{array}{l}\text { Relieves fever, diarrhea, } \\
\text { stomachache, ulcer }\end{array}$ \\
\hline \multicolumn{7}{|l|}{ Lecythidaceae } \\
\hline $\begin{array}{l}\text { Petersianthus } \\
\text { quadrialatus (Merr.) } \\
\text { Merr }\end{array}$ & $\begin{array}{l}\text { Philippine } \\
\text { Rosewood }\end{array}$ & Marakamang & Tree & Leaves & $\begin{array}{l}\text { Heat over fire and place } \\
\text { directly on affected area }\end{array}$ & $\begin{array}{l}\text { Relief for abdominal pain due } \\
\text { to dysmenorrhea, treats hernia } \\
\text { "danlak" in men }\end{array}$ \\
\hline \multicolumn{7}{|l|}{ Lyrathaceae } \\
\hline $\begin{array}{l}\text { Lagerstroemia } \\
\text { speciosa Pers. }\end{array}$ & $\begin{array}{l}\text { Queen's } \\
\text { flower }\end{array}$ & Banaba & Tree & Leaves & $\begin{array}{l}\text { Boil in water and drink } \\
\text { decoction }\end{array}$ & Treats kidney infection \\
\hline & & & & Bark & & $\begin{array}{l}\text { Cures diarrhea and abate } \\
\text { coughing with blood "sugpa" }\end{array}$ \\
\hline
\end{tabular}




\begin{tabular}{|c|c|c|c|c|c|c|}
\hline \multicolumn{7}{|l|}{ Meliaceae } \\
\hline $\begin{array}{l}\text { Sandoricum } \\
\text { koetjape Merr. }\end{array}$ & $\begin{array}{l}\text { Wild } \\
\text { mangosteen }\end{array}$ & Santol & Tree & Fruit & Open and eat fleshy part & Treats diarrhea \\
\hline \multicolumn{7}{|l|}{ Menispermaceae } \\
\hline $\begin{array}{l}\text { Tinospora crispa } \\
\text { (L.) Hook.f. \& } \\
\text { Thomson }\end{array}$ & $\begin{array}{l}\text { Heavenly } \\
\text { elixir }\end{array}$ & $\begin{array}{l}\text { Panjawan or } \\
\text { panyawan }\end{array}$ & Vine & Stem & Scrape the stem and eat & $\begin{array}{l}\text { Eliminate ingested poison or } \\
\text { toxic chemical(s) }\end{array}$ \\
\hline \multicolumn{7}{|l|}{ Moraceae } \\
\hline $\begin{array}{l}\text { Ficus heteropluera } \\
\text { var. mindanaensis } \\
\text { (Warb.) Corner }\end{array}$ & Balite & $\begin{array}{l}\text { Dalakit or } \\
\text { Dayakit }\end{array}$ & Tree & Bark & $\begin{array}{l}\text { Heat over fire and wrap } \\
\text { around the affected area }\end{array}$ & Heals fractures and dislocation \\
\hline \multirow[t]{3}{*}{$\begin{array}{l}\text { Ficus septica } \\
\text { Burm.f. }\end{array}$} & $\begin{array}{l}\text { Septic fig } \\
\text { (hauili) }\end{array}$ & Labnog & Tree & Leaves & $\begin{array}{l}\text { Heat over fire and apply } \\
\text { directly on affected area }\end{array}$ & Relief from headache \\
\hline & & & & $\begin{array}{l}\text { Young } \\
\text { shoot }\end{array}$ & $\begin{array}{l}\text { Boil in water and drink } \\
\text { decoction }\end{array}$ & Relieves stomachache \\
\hline & & & & Fruit & $\begin{array}{l}\text { Squeeze minimal amount of } \\
\text { juice over the affected area }\end{array}$ & $\begin{array}{l}\text { Cures skin disease such as } \\
\text { warts }\end{array}$ \\
\hline \multicolumn{7}{|c|}{ J } \\
\hline $\begin{array}{l}\text { Ficus variegata } \\
\text { Blume }\end{array}$ & $\begin{array}{l}\text { Red-stem } \\
\text { fig } \\
\text { (tangisang- } \\
\text { bayawak) }\end{array}$ & Agahon & Tree & Sap & $\begin{array}{l}\text { Cut a portion of the stem to } \\
\text { extract sap and put some } \\
\text { drops on the affected area }\end{array}$ & Relieves pain during toothache \\
\hline $\begin{array}{l}\text { Trophis philippinensis } \\
\text { (Bur.) Corner }\end{array}$ & N/A & Panhabagat & Tree & Leaves & $\begin{array}{l}\text { Boil in water and drink } \\
\text { decoction }\end{array}$ & Relieves fatigue \\
\hline \multicolumn{7}{|l|}{ Moringaceae } \\
\hline $\begin{array}{l}\text { Moringa oleifera } \\
\text { Lam. }\end{array}$ & $\begin{array}{l}\text { Drumstick } \\
\text { tree }\end{array}$ & $\begin{array}{l}\text { Kalamunggay or } \\
\text { kamunggay }\end{array}$ & Tree & Roots & $\begin{array}{l}\text { Boil in water and drink } \\
\text { decoction }\end{array}$ & Relieves fatigue \\
\hline \multicolumn{7}{|l|}{ Myrtaceae } \\
\hline Psidium guajava $\mathrm{L}$. & Guava & Bayabas & Tree & $\begin{array}{l}\text { Young } \\
\text { leaves }\end{array}$ & $\begin{array}{l}\text { Boil in water, use as an } \\
\text { antiseptic wash or } \\
\text { disinfectant }\end{array}$ & Heals wound \\
\hline $\begin{array}{l}\text { Syzygium aqueum } \\
\text { (Burm.f.) Alston }\end{array}$ & Water apple & Tambis & Tree & Roots & $\begin{array}{l}\text { Boil in water, use as an } \\
\text { antiseptic wash or } \\
\text { disinfectant }\end{array}$ & Heals wound \\
\hline \multicolumn{7}{|l|}{ Muntingiaceae } \\
\hline $\begin{array}{l}\text { Muntingia calabura } \\
\text { L. }\end{array}$ & $\begin{array}{l}\text { Jamaica } \\
\text { cherry }\end{array}$ & Mansanitas & Tree & $\begin{array}{l}\text { Young } \\
\text { shoot }\end{array}$ & $\begin{array}{l}\text { Boil leaves in water and drink } \\
\text { decoction }\end{array}$ & Dengue \\
\hline \multicolumn{7}{|c|}{ Musaceae } \\
\hline $\begin{array}{l}\text { Musa x paradisiaca } \\
\text { L. }\end{array}$ & Banana & Saging (tundan) & Herb & $\begin{array}{l}\text { Young } \\
\text { leaves }\end{array}$ & $\begin{array}{l}\text { Put leaves directly on the } \\
\text { lower portion of the abdomen }\end{array}$ & $\begin{array}{l}\text { Help induce normal urination } \\
\text { during "bus-aw" (difficulty or } \\
\text { urinating in discontinuous } \\
\text { manner), gives relief by giving } \\
\text { a 'cooling effect' }\end{array}$ \\
\hline \multicolumn{7}{|l|}{ Piperaceae } \\
\hline $\begin{array}{l}\text { Peperomia pellucida } \\
\text { (L.) Kunth. }\end{array}$ & Shiny bush & Sinaw-sinaw & Herb & $\begin{array}{l}\text { Leaves } \\
\text { and stem }\end{array}$ & $\begin{array}{l}\text { Put the leaves and stem in a } \\
\text { glass of water and drink the } \\
\text { infused water four times a } \\
\text { day to relieve pain or induce } \\
\text { urination }\end{array}$ & $\begin{array}{l}\text { Cures arthritis, } \\
\text { Kidney infection }\end{array}$ \\
\hline \multicolumn{7}{|l|}{ Poaceae (Graminae) } \\
\hline $\begin{array}{l}\text { Cymbopogon } \\
\text { citratus DC. Stapf }\end{array}$ & $\begin{array}{l}\text { Lemon } \\
\text { grass }\end{array}$ & Tanglad & Grass & $\begin{array}{l}\text { Whole } \\
\text { plant }\end{array}$ & $\begin{array}{l}\text { Boil in water and drink } \\
\text { decoction three times a day }\end{array}$ & Lowers hypertension \\
\hline $\begin{array}{l}\text { Cymbopogon nardus } \\
\text { (L.) Rendle. }\end{array}$ & $\begin{array}{l}\text { Citronella } \\
\text { grass }\end{array}$ & Siniswil & Grass & $\begin{array}{l}\text { Whole } \\
\text { Plant }\end{array}$ & $\begin{array}{l}\text { Pound until soft and apply } \\
\text { directly to affected area }\end{array}$ & $\begin{array}{l}\text { Anti-rabies; } \\
\text { Insect repellent }\end{array}$ \\
\hline $\begin{array}{l}\text { Eleusine indica (L.) } \\
\text { Gaernt. }\end{array}$ & Water apple & $\begin{array}{l}\text { Paragis o bila- } \\
\text { bila }\end{array}$ & Grass & $\begin{array}{l}\text { Whole } \\
\text { plant }\end{array}$ & $\begin{array}{l}\text { Boil in water and drink } \\
\text { decoction }\end{array}$ & $\begin{array}{l}\text { Relieves over fatigue and } \\
\text { flatulence }\end{array}$ \\
\hline Zea mays L. & Corn & Mais & Grass & $\begin{array}{l}\text { Young } \\
\text { hair }\end{array}$ & $\begin{array}{l}\text { Put in a glass of water and } \\
\text { drink three times a day }\end{array}$ & $\begin{array}{l}\text { Stimulate urination and treats } \\
\text { kidney trouble }\end{array}$ \\
\hline \multicolumn{7}{|l|}{ Rubiaceae } \\
\hline $\begin{array}{l}\text { Neonauclea } \\
\text { formicaria (Elmer) } \\
\text { Merr. }\end{array}$ & Bangkal & $\begin{array}{l}\text { Ambabayud or } \\
\text { Ambabalod }\end{array}$ & Tree & $\begin{array}{l}\text { Young } \\
\text { shoot }\end{array}$ & $\begin{array}{l}\text { Boil in water and drink } \\
\text { decoction thrice a day }\end{array}$ & Amoeba \\
\hline $\begin{array}{l}\text { Uncaria lanosa } \\
\text { Wall. } \\
\text { Subsp.philippinensis } \\
\text { (Elmer) Gruezo }\end{array}$ & N/A & Kawilan & Tree & Roots & $\begin{array}{l}\text { Boil in water and drink } \\
\text { decoction }\end{array}$ & Relieves fatigue \\
\hline
\end{tabular}




\begin{tabular}{|c|c|c|c|c|c|c|}
\hline \\
\hline $\begin{array}{l}\text { Citrus maxima } \\
\text { (Burmf.) Merr. }\end{array}$ & $\begin{array}{l}\text { Grapefruit } \\
\text { (pomelo) }\end{array}$ & Buongon & Tree & Leaves & $\begin{array}{l}\text { Pound until soft and apply } \\
\text { directly to infected area }\end{array}$ & Relieves headache \\
\hline \multicolumn{7}{|l|}{ Rutaceae } \\
\hline $\begin{array}{l}\text { Citrus x microcarpa } \\
\text { Bunge }\end{array}$ & Kalamansi & Lemonsito & Tree & Fruit & $\begin{array}{l}\text { Squeeze the juice into a glass, } \\
\text { add water and drink }\end{array}$ & Cures cough \\
\hline $\begin{array}{l}\text { Glycosmis elmeri } \\
\text { Merr. }\end{array}$ & Gin berry & Tambagisa & Tree & Fruit & Eat freshly picked fruit & Expels poison ingested \\
\hline \multicolumn{7}{|l|}{ Solanaceae } \\
\hline $\begin{array}{l}\text { Capsicum frutescens } \\
\text { L. }\end{array}$ & Chili & Sili & Herb & Leaves & $\begin{array}{l}\text { Crush the leaves, mix with } \\
\text { coconut oil and rub or } \\
\text { massage on the chest }\end{array}$ & $\begin{array}{l}\text { Relieves discomfort from } \\
\text { asthma }\end{array}$ \\
\hline \multicolumn{7}{|l|}{ Urticaceae } \\
\hline $\begin{array}{l}\text { Leucosyke } \\
\text { capitellata (Poir.) } \\
\text { Wedd. }\end{array}$ & $\begin{array}{l}\text { Tooth } \\
\text { scrubber }\end{array}$ & $\begin{array}{l}\text { Alagasi or } \\
\text { Anagasi }\end{array}$ & Shrub & Bark & $\begin{array}{l}\text { Scrape the mature skin of the } \\
\text { stem to obtain the bark and } \\
\text { chew }\end{array}$ & Heals mouth ulcer "luas" \\
\hline \multirow{2}{*}{$\begin{array}{l}\text { Pipturus } \\
\text { arborescens (Link.) } \\
\text { C. Rob. }\end{array}$} & Dalunot & Handayamay & Shrub & Roots & $\begin{array}{l}\text { Boil in water and drink } \\
\text { decoction }\end{array}$ & Relief from headache \\
\hline & & & & & $\begin{array}{l}\text { Scrape the leaves and then } \\
\text { place them on the affected } \\
\text { area }\end{array}$ & $\begin{array}{l}\text { Treat swelling to help subside } \\
\text { inflammations }\end{array}$ \\
\hline $\begin{array}{l}\text { Verbenaceae } \\
\text { Stachytarpheta } \\
\text { jamaicensis (L.) } \\
\text { Vahl. }\end{array}$ & $\begin{array}{l}\text { Bastard } \\
\text { vervain }\end{array}$ & Kanding-kanding & Shrub & Roots & $\begin{array}{l}\text { Boil in water and drink } \\
\text { decoction }\end{array}$ & $\begin{array}{l}\text { Abates coughing with blood } \\
\text { "sugpa" }\end{array}$ \\
\hline \multicolumn{7}{|l|}{ Vitaceae } \\
\hline $\begin{array}{l}\text { Leea guineensis } \mathrm{G} . \\
\text { Don }\end{array}$ & Leea & Manipis & Shrub & Bark & $\begin{array}{l}\text { Put bark in a glass of water } \\
\text { and drink the infused water }\end{array}$ & $\begin{array}{l}\text { Relieves fatigue, stomachaches, } \\
\text { diarrhea (children), ulcer, } \\
\text { toothache; heals wound, skin } \\
\text { diseases, eliminates poison and } \\
\text { an anti-rabies }\end{array}$ \\
\hline \multicolumn{7}{|l|}{ Zingiberaceae } \\
\hline Curcuma longa $\mathrm{L}$. . & Turmeric & Duyaw & Herb & Rhizome & $\begin{array}{l}\text { Preheat rhizome, squeeze to } \\
\text { Obtain extract, mix with } \\
\text { coconut oil and apply on the } \\
\text { affected area }\end{array}$ & Cures bruise and boils \\
\hline $\begin{array}{l}\text { Kaempferia } \\
\text { galangal Linn. }\end{array}$ & $\begin{array}{l}\text { Resurrection } \\
\text { lily }\end{array}$ & Kisol & Herb & Leaves & $\begin{array}{l}\text { Boil in water and drink } \\
\text { decoction }\end{array}$ & Relieves cough \\
\hline & & & & & $\begin{array}{l}\text { Place leaves in a glass of } \\
\text { water and drink the infusion }\end{array}$ & Relieves fatigue \\
\hline $\begin{array}{l}\text { Zingiber officinale } \\
\text { Roscoe }\end{array}$ & Ginger & Luy-a & Herb & Rhizome & $\begin{array}{l}\text { Pound until soft then mix } \\
\text { with "sagbong" and add a } \\
\text { small amount of kerosene }\end{array}$ & Flatulence \\
\hline \multicolumn{7}{|c|}{ PTERIDOPHYTES (fern and fern-allies) } \\
\hline \multicolumn{7}{|c|}{ Athyriaceae } \\
\hline $\begin{array}{l}\text { Diplazium } \\
\text { esculentum (Retz.) } \\
\text { Sw. }\end{array}$ & $\begin{array}{l}\text { Vegetable } \\
\text { fern }\end{array}$ & Pako & $\begin{array}{l}\text { Fern or } \\
\text { fern } \\
\text { allies }\end{array}$ & Leaves & $\begin{array}{l}\text { Pick fresh leaves and put } \\
\text { directly on affected area }\end{array}$ & Anti-rabies \\
\hline \multicolumn{7}{|l|}{ Marratiaceae } \\
\hline $\begin{array}{l}\text { Angiopteris } \\
\text { palmiformis (Cav.) } \\
\text { C. Chr. }\end{array}$ & Giant fern & $\begin{array}{l}\text { Makaraghu } \\
\text { (pakong } \\
\text { kalabaw) }\end{array}$ & $\begin{array}{l}\text { Fern or } \\
\text { fern } \\
\text { allies }\end{array}$ & Roots & $\begin{array}{l}\text { Pound thoroughly to extract } \\
\text { the juice and apply directly to } \\
\text { affected area }\end{array}$ & $\begin{array}{l}\text { Heals swelling and } \\
\text { inflammation }\end{array}$ \\
\hline
\end{tabular}

